\title{
Competitive personalities of students - future engineers of the oil and gas industry
}

\author{
Personalidades competitivas de alunos - futuros engenheiros da \\ indústria de petróleo e gás
}

\section{Personalidades competitivas de estudiantes - futuros ingenieros de la industria del petróleo y gas}

\author{
Natalia V. Kamenez ${ }^{1}$ iD), Ekaterina A. Semenova ${ }^{1}$ (iD) \\ ${ }^{1}$ Industrial University of Tyumen, Tyumen, Russia. \\ Corresponding author: \\ Natalia V. Kamenez \\ Email: Kameneznv@mail.ru
}

Kamenez, N. V., \& Semenova, E. A. (2021). Competitive personalities of students - future engineers of the oil and gas industry. Revista Tempos e Espaços em Educação, 14(33), e16281. http://dx.doi.org/10.20952/revtee.v14i33.16281

\begin{abstract}
The goal of students' professional training in the oil and gas field is to form a competitive, highly qualified graduate. This article describes the criteria and requirements necessary for the formation of a competitive specialist in the oil and gas industry, namely, a future engineer, and emerging issues and problems faced by both university teachers and students. This work was carried out based on the analysis of scientific literature, which described the research of scientists on the competitiveness of graduates of technical universities in current conditions, as well as on the analysis of the results of the implementation of pedagogical conditions for the development of the qualities of a competitive personality of students. The implementation of the conditions proposed within the framework of this work contributes to the training of a highly qualified specialist who is ready to "survive" in modern conditions of competition.
\end{abstract}

Keywords: Students. Future engineers. Competitiveness. Competencies. Analysis.

\section{RESUMO}

O objetivo da formação profissional dos alunos na área de petróleo e gás é formar uma pósgraduação competitiva e altamente qualificada. Este artigo descreve os critérios e requisitos necessários para a formação de um especialista competitivo na indústria de petróleo e gás, ou seja, um futuro engenheiro, e questões emergentes e problemas enfrentados por professores e alunos universitários. Este trabalho foi realizado com base na análise da literatura científica, que descreveu a investigação de cientistas sobre a competitividade dos licenciados em universidades técnicas nas condições actuais, bem como na análise dos resultados da implementação de condições pedagógicas para o desenvolvimento de as qualidades de uma personalidade competitiva dos 
alunos. A concretização das condições propostas no âmbito deste trabalho contribui para a formação de um especialista altamente qualificado e pronto a "sobreviver" nas modernas condições de competição.

Palavras-chave: Alunos. Futuros engenheiros. Competitividade. Competências. Análise.

\section{RESUMEN}

El objetivo de la formación profesional de los estudiantes en el campo del petróleo y el gas es formar un graduado competitivo y altamente calificado. Este artículo describe los criterios y requisitos necesarios para la formación de un especialista competitivo en la industria del petróleo y el gas, es decir, un futuro ingeniero, y los problemas y problemas emergentes que enfrentan tanto los docentes universitarios como los estudiantes. Este trabajo se realizó con base en el análisis de la literatura científica, que describió la investigación de científicos sobre la competitividad de los egresados de universidades técnicas en las condiciones actuales, así como en el análisis de los resultados de la implementación de condiciones pedagógicas para el desarrollo de las cualidades de una personalidad competitiva de los estudiantes. La implementación de las condiciones propuestas en el marco de este trabajo contribuye a la formación de un especialista altamente calificado y listo para "sobrevivir" en las modernas condiciones de competencia.

Palabras clave: Estudiantes Futuros ingenieros. Competitividad. Competencias. Análisis.

\section{INTRODUCTION}

Society today is characterized by frequent changes in social and economic conditions, which have led to the modernization of the current education system. This is what led to the further development of innovative processes in the system of training and education (Saitbagina, 2015; Akter, 2020).

The transition to a market model of the economy led to the emergence and development of a competitive professional environment. A number of difficulties appeared for both students and universities, which should provide an opportunity for a future engineer's high-quality and effective professional development. For example, the difficulties of adaptation, socialization, and demand for an engineer in the oil and gas industry, employment issues, as well as difficulties in the interaction between members of the workforce in a competitive environment (Maksimova, 2005; Mathew \& Chung, 2020).

There is a change in the requirements for knowledge, personal and professional qualities, and skills of modern specialists in the oil and gas industry. The competitiveness of a university graduate is the main requirement and criterion for assessing the education system (Baumann \& Harvey, 2021).

Today in the scientific community, there is an opinion that the level of theoretical elaboration of the problem of individual competitiveness is rather low. Thus, the need for further study of the categorical apparatus, a deeper understanding of the concepts of "competition", "competitiveness" is recognized. The issue of identifying the qualities of a competitive personality is also controversial. In particular, the aspect of identifying, structuring, and developing overprofessional specific qualities of a person that determine one's competitiveness requires a more thorough study, since in many studies, in fact, it is about the development of professionally important qualities in the context of achieving the heights of professionalism, professional competence (Zaitseva et al., 2016).

The competitiveness of students is ensured by the success of their professional activities, which in turn is determined by the totality of professional and personal qualities. According to the results of the research carried out, we can say that at present, modern students do not have the necessary qualities in order to become competitive in real conditions. This is what determines the 
interest of scientists in studying the problem of research and the formation of the qualities of competitiveness in the learning process (Khazova, 2011; Arkhipov et al., 2016).

Today, the theoretical elaboration of the problem of the competitiveness of students' personalities is at a rather low level. There is a need for a deeper understanding of concepts such as "competition" and "competitiveness" in this regard. Also, do not forget about the issue of forming the necessary qualities of a competitive personality of students through the educational process. Many studies talk about the development of professionally significant qualities of a future specialist and professional competencies. A more thorough study of identifying, structuring and developing professional specific qualities of an individual is required, which determine its competitiveness (Rakhuba, 2017; Mostafa \& Lim, 2020).

The practical value of this article is determined by the results of the application of the findings of the study in the TIU branch in Surgut, as well as the creation of a theoretical basis for the development of programs and methods for the formation of the necessary qualities of future engineers, in a competitive environment.

\section{METHODOLOGY}

The study's methodological basis was a personality-activity approach that ensures the development of a student's personality through enrichment, the transformation of his experience while recognizing the value of individual experience and joint experience, and the value of interpersonal interaction.

With regard to pedagogical research, it should be noted that the issues of the formation of a competitive personality are of high interest to scientists. This is manifested in the fact that, firstly, competitiveness as a characteristic of a specialist's personality becomes the subject of special research. Secondly, in many works devoted to the study of other aspects of the modern educational process, competitiveness is noted as an urgent requirement for the quality of professional training of specialists.

The category of "competitiveness" has moved into the category of pedagogical concepts from economics, in which the history of the issue has been studied for more than two hundred years (from the second half of the 18th century). Thus, educational scientists find guidelines for understanding competitiveness as a quality of a specialist's personality in the field of economic research, revealing the socio-economic nature of the phenomenon of competitiveness.

In modern pedagogical research, the competitiveness of an individual is viewed in a very diverse way: as a personality quality; a complex of personality traits; complex individual education; integral characteristic of a specialist; the property of a specialist, personality; basic foundation of personality; an indicator of the quality of the university's work; the condition for a new qualitative state of the specialist; the very new state of the specialist; a dynamic system consisting of a number of components; an indicator of the qualification level of a specialist, as well as an indicator of a specialist's capabilities, an indicator of a high level of personality development; one of the components of the social competence of a specialist, etc.

Thus, as the basis of a specialist's competitiveness, an individual's competitiveness can be represented as follows. This is a characteristic of a specialist's personality, for which the development of special qualities is characteristic. Thanks to these qualities, a competitive person acts as a subject of activity, the results of which ensure his success, demand, and the status he wants in a specific social and professional environment in conditions of interpersonal interaction.

The theoretical analysis results allowed us to determine the initial directions in identifying a competitive personality's complex qualities. As a result of the analysis, we obtained a list of qualities of a competitive personality, represented by two groups of qualities. A person who is characterized by the formation of these qualities can be characterized as a competitive person. 
The qualities of a competitive personality include social orientation in activities; the ability to act effectively in a "relative environment," "relative to Others"; reflexivity; purposefulness; striving and the ability for self-development; the ability to self-organize activities.

The content of the process of becoming a competitive personality at the stage of university preparation includes the development of the qualities of a student's competitive personality, which are manifested and developed in educational activities in the conditions of university education, in situations of interpersonal educational interaction with other subjects of the learning process.

The process of development of a student's competitive personality should be built in two directions: the development of a student's personality as a subject of interpersonal interaction in the context of the implementation of functions, social roles "customer-performer," as well as the development of a student's personality as a subject of self-development. Taking into account these components of the activity of a competitive specialist in the educational process of a university can ensure the integrity of the development process of a student as a competitive person at the stage of university preparation.

In the context of professional education at a technical university, the solution to the problem of forming a competitive personality of a future engineer is largely associated with the use of the capabilities of the humanities. In this regard, the pedagogical potential of the humanities makes it possible to provide: the value-semantic basis of the professional development of the student's personality; conditions for the acquisition and reflection of the subjective experience of interpersonal interaction in the social environment; the formation of skills in educational activities that contribute to the development of the qualities of a competitive personality.

The pedagogical conditions for the development of the qualities of a student's competitive personality in the learning process should ensure the possibility of self-development of the student as a subject of educational activity in specially organized educational situations where the qualities of a student's competitive personality are in demand.

To implement the pedagogical conditions for the development of students' qualities of a competitive personality in the process of studying humanitarian disciplines, a special organization of the learning process is required, which provides: activity-oriented goal-setting of students in learning; self-development by students of the experience of interpersonal educational interaction in educational situations of setting and solving multi-level educational tasks; constant "high-quality" feedback on the conditions, process, and result of interaction between subjects of the learning process.

The use of pedagogical means of developing the qualities of a student's competitive personality in the process of teaching in the humanities should contribute to the student's selfdevelopment as a subject of educational activity, mastering adequate methods of interpersonal interaction in situations of setting and solving educational problems, forming a value attitude towards participants in educational interaction, acquiring and understanding interpersonal experience. Educational interaction, the experience of self-development.

Thus, the pedagogical conditions for the development of the qualities of a student's competitive personality should include a set of interrelated opportunities, content, means of selfdevelopment of the student's personality in the direction of his self-improvement as a participant in interpersonal interaction and a subject of self-development.

In accordance with the purpose of the pedagogical research, experimental work was carried out with 1-4 year students enrolled in bachelor's programs in such areas of training as: "Operation and maintenance of oil production facilities" and "Construction and maintenance of transport systems, storage, and marketing of hydrocarbons." The study was carried out on the basis of the TIU branch in Surgut, which is one of the clear representatives of educational organizations that train specialists for the oil and gas industry. As a result of the analysis, a methodology was identified, the purpose of which is to form the competitiveness of students as future engineers. 


\section{RESULTS}

The program of the experiment included the organization of the ascertaining and formative stages. The content of the ascertaining experiment included collecting and analyzing empirical data on the existing practice of studying economic disciplines by students from the point of view of its compliance with the pedagogical conditions for the development of a student's competitive personality. At the ascertaining stage, the contingent of students of economic disciplines (students of 1-4 courses) was examined. We used the following methods: questioning, conversation, observation, essay writing.

First of all, the research aimed to determine the level of students' knowledge about the qualities of a competitive personality (cognitive criterion). For this purpose, we conducted a survey, which covered 56 students of 2-4 courses. In addition, in the classroom with the students, group discussions were held on the topic "What is a competitive person?"

To identify students' ideas about a competitive personality's qualities, they were asked to choose the most important characteristics of an engineer, ensuring his competitiveness in professional activity. The list of the proposed characteristics included the characteristics of an engineer of various specializations, presented in professional, educational standards, as well as the qualities of a competitive personality that we highlighted. When analyzing the results obtained, we proceeded from the fact that despite the undoubted importance of all individual presented personal characteristics of an engineer in professional activity, a deeper understanding of the essence of a person's competitiveness is associated with an understanding of its connection with the sphere of interpersonal social and professional interaction, as well as with the sphere of self-government by a person with his own self-development. ...

Students' answers demonstrate differences in their assessment of technical knowledge, highly specialized skills, on the one hand, and the qualities of a competitive personality, on the other hand. Thus, the overwhelming majority of students consider the most important characteristics that ensure the competitiveness of an engineer are deep technical knowledge (81\%), developed technical thinking (84\%), and the ability to solve technical problems (69\%). A significantly smaller number of students recognize the importance of characteristics that can be attributed to the sphere of a person's competitiveness - the ability to self-criticism (33\%), the ability to self-organize (24\%), sensitivity (11\%), etc. It was found that the qualities of a competitive person, providing effective interpersonal interaction of an engineer in professional activity, in general, are valued by students to a lesser extent than the qualities of a competitive personality necessary for strategic planning and implementation of their professional development, "movement." For example, the ability to understand others and communicate with people is recognized as important qualities by $19 \%$ and $39 \%$ of students, respectively, while dedication and the desire to plan their career are $59 \%$ and $54 \%$.

The analysis of the data obtained shows that students have incomplete, fragmentary ideas about a competitive person's qualities, which corresponds to the average and low level of knowledge necessary for a competitive person's self-development. At the same time, the students demonstrated a higher level of understanding of the importance of a competitive personality that ensures their professional self-development.

The problem is aggravated by the fact that students are not ready to act as full-fledged subjects of educational activity, subjects of self-development in the current process of studying economic disciplines. The study showed that in the learning process, such qualities of a student's competitive personality as purposefulness in achieving educational goals, self-organization of activities, self-control, aspiration and ability for self-development are insufficiently manifested. Insufficient formation of the subject position of students, insufficient manifestation by students of the qualities of a student's competitive personality in training indicates insufficient implementation of pedagogical conditions for the self-development of a student's competitive personality and 
determines the urgency of the problem of increasing the developmental impact of the process of studying economic disciplines on the student's personality.

From the point of view of organizing the process of studying economic disciplines by students, it can be noted that in current practice, there is a problem of insufficient correspondence between the organizational and pedagogical conditions of the teaching process to the task of developing a student's competitive personality. The need to provide conditions for the selfdevelopment of a competitive student's personality in educational activities requires the improvement of content, teaching aids, as well as the organization of educational interaction between teachers and students. The emphasis in teaching on the cognitive rather than on the activity sphere of the student's personality makes it difficult to provide the value-semantic basis for the self-development of the student's competitive personality. In this regard, there is a need to saturate the learning process with activity-oriented tasks, which contributes to the selfdevelopment of a student as a subject of educational activity, a subject of his own self-development as a complex, long process that requires the manifestation and development of a complex of qualities of a competitive personality. In turn, the solution to this problem necessitates the development of appropriate didactic tools.

The study showed that in the practice of organizing the learning process by teachers, the acquisition and reflection by students of the experience of interpersonal educational interaction, the formation of educational skills, which is important for the development of the subjectivity of students in situations of interpersonal educational interaction as an important aspect of the manifestation of a student's competitive personality, are insufficiently provided.

In addition, there is a reserve for increasing the readiness of teachers for pedagogical activities aimed at developing a competitive personality of a student in the current teaching practice. This potential is associated with the formation of a more valuable attitude of teachers to the holistic process of development of the personal competitiveness of students, as well as with an increase in the readiness of teachers to implement interpersonal educational interaction, which contributes to the self-development of the qualities of a student's competitive personality.

Thus, in the course of the study, a short correspondence of the current practice of organizing the learning process in the humanities to the pedagogical conditions of the development of the qualities of a student's competitive personality was revealed. Thus, the need to improve humanitarian training was confirmed in the direction of a fuller realization of its pedagogical potential in the development of a student's competitive personality. We associate the solution of this problem with the development and implementation of a model of the development of the qualities of a student's competitive personality in the process of studying the humanities.

At the formative stage of the experimental work, the effectiveness of the proposed model of the process of developing the qualities of a student's competitive personality was confirmed. The purposeful use of the complex of didactic tools developed by us, aimed at developing the qualities of a student's competitive personality, provided the opportunity for students to manifest and selfdevelop these personal qualities in educational activities.

As an important manifestation of the overall result of the implementation of the proposed pedagogical measures, one can note an increase in the degree of subjectivity of students in the learning process as a process of educational interaction aimed at developing a competitive personality of a student. This became possible due to the acquisition and understanding by students of their experience of interpersonal educational interaction as its full-fledged participants, subjects of self-development. As a result, students have formed a more conscious, more holistic attitude and ideas regarding the process of their professional development in the course of studying the humanities as a component of the stage of their personal and professional development. This had a positive effect on the educational activities of students, its self-organization in accordance with the goals of learning. 
The results of the practical implementation of the model of the process of developing the qualities of a student's competitive personality in the process of studying economic disciplines were evaluated on the basis of the selected criteria: cognitive, motivational-value, and operationalactivity. The data of monitoring the development of students' qualities of a student's competitive personality demonstrated a more pronounced positive dynamic of all indicators among students who studied in the context of the implementation of the proposed pedagogical model.

For the formation of competitiveness among students of the TIU branch in Surgut it is necessary: to develop personal qualities of students, including competitiveness; create an educational space of the branch with conditions for the manifestation of initiatives and competitiveness by students; to create a holistic integrative education system in the branch, which will contribute to the preparation of a qualified graduate, with the necessary professional qualities formed; create conditions for self-determination of students, including changes in the system of worldview, cultural and ethical development; organize a comprehensive system of psychological and pedagogical impact on students using vocational and educational structures; to ensure stable and functional work in various types of activities (research, educational, practical, professional, etc.); to ensure stable interaction between the branch and professional institutions, thereby providing students with the opportunity to participate in multidisciplinary training; to expand the variety of activities that are organized within the educational work of students, as well as in the form of practices; to determine the target setting and components (meaningful, technological, expertevaluative) necessary in the process of forming the competitiveness of students' personality (Arkhipov et al., 2016; Mostafa \& Lim, 2020).

Bringing up a competitive student is the goal of any modern university. Considering the needs of the market, the target setting will ensure the need for the formation of special qualities and abilities of the individual and specific components of competitiveness. These provisions will make it possible to determine its structure specifically for university students, taking into account social needs and requests for specialists (Arkhipov et al., 2014).

A modern approach to solving the problem of employment of future engineers is the implementation of the principle of personality-oriented employment, in which the personal and professional abilities of a graduate of a higher educational institution are linked to the current and future personnel needs of the enterprise. In view of this, the issue of forming the necessary qualities for a competitive specialist has a special place.

Thus, we can say that a competitive student specialist is a specialist who can achieve any goals and tasks set for him in given conditions by using methods for solving a number of problems and certain personal qualities in practice.

The competitiveness of students can be viewed through personal and professional components. Personal components include a number of specific individual stable functions that help the future engineer to perform any work more efficiently (Zaitseva et al., 2016). Each function of this component includes certain components: character traits (hard work, striving for constant selfdevelopment and professional growth); abilities (creativity, ability to take risks, clarity of purpose and value orientations, leadership qualities, tolerance); state (resistance to stress, congruence, sthenism).

Diligence is a person's positive attitude to the labor process, manifested inactivity, initiative, enthusiasm, and satisfaction with the labor process itself. The development of self-awareness, selfknowledge, self-education, and self-actualization (a person's striving for the fullest possible identification and development of their capabilities) determine the desire of the future engineer for constant self-development (Maksimova, 2005; Mathew \& Chung, 2020). The desire for continuous professional growth is realized through the development of abilities necessary and sufficient to achieve socially acceptable efficiency in the engineering profession. 
A creative approach in work is determined by the ability to interact with reality actively and the development of creative individuality, represented by the intellectual and motivational spheres of the psyche, including motivational readiness, reflection, and creativity of thinking. The clarity of value orientations makes it possible to differentiate objects of reality according to their significance. The development of values and meanings helps: assess your capabilities and be aware of yourself as an individual, direct your reasoning about professional actions, and use engineering erudition (a stock of necessary knowledge that is used to solve certain problems). The ability to take risks (to act in a situation of choice with uncertainty in the outcome of events) is determined by a high level of engineering intuition and observation - qualities that enable one to take motivational and justified risk dictated by various situations. Leadership qualities mean the ability to make responsible decisions, the organization of joint activities of the team, and the regulation of relations between people within it - all this depends on the individual psychological characteristics of the future engineer, his creative thinking and communication skills, which allow organizing and controlling the space and time of communication (Andreev, 2007). Also, an important component of a future engineer's competitiveness is tolerance - the ability to productive (constructive) interaction in a situation of ideological competition, mismatched views, and ideas, values, etc.

Resilience to stress is of particular importance in a competitive environment. This is a stable mental state, which is characterized by emotional stability under given conditions. The integrated state of the future engineer's personality, which characterizes the consistency of all aspects of the psyche responsible for behavioral reactions and social experience, is characterized as congruence. In its formation, the most important are: the development of intuitive processes, the ability to assess their capabilities, awareness of their own individuality. Sthenism is understood as a psychophysical state characterized by stability and high indicators of the body's vital activity (Tamarskaya, 2004). As a result, the model of a competitive specialist in the oil and gas industry looks like this

(Fig. 1):

Figure 1. Model of a competitive specialist in the oil and gas industry to advanced technologies in the implementation of professionally important functions

Professional
competencies (theoretical
knowledge and practical skills
by profession)

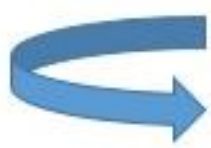

\section{Individual and personal competencies}

(character traits, abilities, condition, and needs)

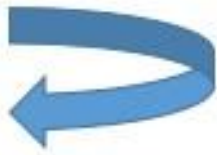

\section{Competitive specialist}

Fonte: Danilova (2008).

Many modern methods, which are aimed at the formation of a competitive student, are focused on an objective assessment of the strengths and weaknesses of their personality in order to build their professional career and successful social growth, including financial security and access

The possibilities of forming the competitiveness of a student's personality are in close relationship with the formation of professional competence of students. In the TIU branch in Surgut, three components determine the potential of the educational and professional space of the university (Fig. 2): professional orientation; professional and personal; professional activity. 
Figure 2. Model of educational and professional space branch of TIU in Surgut.

\begin{tabular}{|l|}
\hline $\begin{array}{l}\text { Professional orientation } \\
\text { component (teaching level) }\end{array}$ \\
\hline $\begin{array}{l}\text { Professional and personal } \\
\text { component (humanization } \\
\text { (creation of conditions for) } \\
\text { interaction between persons or } \\
\text { a group of persons) }\end{array}$ \\
\hline $\begin{array}{l}\text { Professional activity } \\
\text { component (participation in } \\
\text { extracurricular and other } \\
\text { activities) }\end{array}$ \\
\hline
\end{tabular}

The professional orientation component of the educational and professional space includes a level of teaching that satisfies students' cognitive needs, the expansion of the network of educational services that best meet students' needs and demands.

The professional and personal component focuses on the future specialist's high-quality training and ensures integrating the educational and professional space. An integral part of this component is the creation of conditions for interpersonal relations in the process of group and intergroup interaction and the culture of pedagogical communication (Khazova, 2011).

The professional-activity component implies the participation of students of the branch in extracurricular and research activities, in the work of self-government bodies of the university, and in institutions of additional education, thanks to which business communication (interaction) between students and teachers takes place. The creation of the university's educational and professional space can help solve a number of organizational, methodological, didactic, and other problems. At the same time, one can single out such components as educational, professional, practical, managerial, financial and economic, research (Arkhipov et al., 2016).

When designing a university's educational and professional space, it is necessary to create psychological, pedagogical, and methodological conditions for the development of a graduate's competitiveness. These include the transfer of fundamental and professional knowledge, skills and competencies, innovative technologies for teaching students, polyprofessionalism of students, which involves mastering additional and related specialties, practice-oriented training. This refers to industrial practices, master classes, seminars, professional creative projects, contests, exhibitions, the introduction of the results of scientific achievements based on the results of coursework, the development of the main components of the personality in the learning process, assistance in the employment of graduates (Fugelova, 2013).

Within the framework of the TIU branch in Surgut, the proposed methodology for the formation of students' competitiveness can be psychological training in the study of the disciplines "Fundamentals of project activity" and "Fundamentals of scientific research."

This psychological training is aimed at mastering by students various skills and abilities of communication with the workforce and directly with the employer; training of future specialists for self-determination; development of information retrieval technology and organization of work, both our own and collective.

Thus, in the TIU branch in Surgut, the disciplines "Fundamentals of Project Activity" and "Fundamentals of Scientific Research" introduce students to the system of planning their own activities, including developing the following indicators of competitiveness in them: clarity of goals and value orientations through planning activities; striving for self-development through selfobservation, self-education, and most importantly - self-realization; striving for continuous professional growth through motivation to achieve success and the ability to regulate activities; 
congruence through an adequate self-assessment of the results of their activities; stress resistance and leadership qualities, by involving students in project and research work, teamwork, etc.

These disciplines have a cognitive orientation focus for future engineers. Projects and research work carried out within these disciplines is implemented through work on a project and participation in competitions - this contributes to the formation of students' professional competence, contributing to a conscious attitude to mastering their chosen profile, planning their career, developing dedication, creativity, hard work, and stress resistance.

Acknowledgments: Not applied.

\section{CONCLUSIONS}

The practical need for competitive specialists determines a modern university's social order for training such specialists who could successfully work in a competitive professional environment. This task meets the needs of the state, industry, and all subjects of the university's educational process.

A consequence of the emergence and awareness of these needs by the scientific community is the relevance of a scientific search for ways to form a competitive personality in the process of professional training at a university. The development of students' qualities of a competitive personality at the stage of university education contributes to their preparation for successful interaction and professional activity in a modern competitive social and professional environment.

Analysis of scientific literature has shown that scientists at an interdisciplinary level are developing the problem of individual competitiveness. In pedagogical research, the insufficient level of its theoretical elaboration is recognized. In particular, this concerns the problem of developing a categorical apparatus, the need for a complete understanding of the content of the categories "competitiveness," "competitive personality," "quality of a competitive personality." One of the urgent tasks is to differentiate the concept of "competitive personality" among other, more or less traditional, generally recognized pedagogical categories.

As part of the study of the pedagogical aspects of a person's competitiveness, modern scientists study a competitive person's structure, determine the qualities of a competitive person, and the pedagogical conditions that contribute to their development. Attempts are also made to comparatively analyze the categories "competitive personality" and "creatively self-developing personality," "self-sufficient personality,"; categories "competitiveness" and "professionalism."

Despite the rather high interest of researchers in this problem, the methodological aspect of studying the competitiveness of a person, associated with the relevance and the need to take into account humanistic principles when developing the content of this category and determining on this basis the pedagogical conditions for the development of a student's personality, has not received due attention in pedagogical science. This aspect of studying the problem of developing a competitive personality in the learning process is essential from the point of view of compliance with the modern humanistic paradigm of higher professional education and its effectiveness, obtaining high-quality, sustainable results.

Based on theoretical and experimental research results, we have analyzed the main theoretical and methodological approaches to the formation of students' competitiveness as future engineers in the oil and gas industry. These approaches were considered on the example of the TIU branch in Surgut. Also, the main components were identified that characterize a competitive specialist, according to which the corresponding model was drawn up. Further, according to the identified model of the educational and professional space of the branch, a methodology (psychological training) of the formation of students' competitiveness in the study of the disciplines "Fundamentals of project activity" and "Fundamentals of scientific research", which are conducted among students of the branch, was proposed. Thus, within the framework of training undergraduate 
students of the TIU branch in Surgut in training "Operation and maintenance of oil production facilities" and "Construction and maintenance of transport, storage, and marketing of hydrocarbons," further work in this direction is expedient.

Authors' Contributions: Natalia V. Kamenez: conception and design, acquisition of data, analysis and interpretation of data, drafting the article, critical review of important intellectual content. Ekaterina A. Semenova: conception and design, acquisition of data, analysis and interpretation of data, drafting the article, critical review of important intellectual content. All authors have read and approved the final version of the manuscript.

Ethics Approval: Not applicable.

Acknowledgments: Not applicable.

\section{REFERENCES}

Akter, H. (2020). Business Graduate-ness and Work-readiness: A Comparative Analysis of Public and Private Universities in Bangladesh. Asian Journal of University Education, 16(3), 59-77.

Andreev, V.I. (2007). About guaranteed ${ }^{\mathrm{TM}}$ quality of higher education and self-development of a competitive personality. Scientific notes of Kazan University. Humanities Series, 149 (1).

Arkhipov A.A., Valetov M.R., Kuzmin A.M. (2014). Self-development of the student's personality in the educational practice of the university using the values of physical culture. Modern educational space: risks and safety: collection of articles. Orenburg: OGPU, 47-49.

Arkhipov, A.A., Kuzmin, F.S., \& Chelpachenko, T.V. (2016). Development of competitiveness of university students.

Danilova, T.A. (2008). Formation of a competitive personality in the educational process of the university. Izvestia of the Russian State Pedagogical University. Al Herzen, 88.

Fugelova, T.A. (2013). From a professionally mobile student to a competitive specialist. Basic Research, 10(6), 13671370.

Khazova, S. A. (2011). Development of a competitive personality in the education system.

Maksimova, E. V. (2005). The development of student competitiveness in the educational process of the university (Doctoral dissertation, [Orenburg. State University]).

Mathew, V. N., \& Chung, E. (2020). University Students' Perspectives on Open and Distance Learning (ODL) Implementation Amidst COVID-19. Asian Journal of University Education (AJUE), 16(4).

Mostafa, H., \& Lim, Y. (2020). Examining the Relationship between Motivations and Resilience in Different International Student Groups Attending US Universities. Journal of International Students, 10(2), 306-319.

Rakhuba, L.F. (2017). Pedagogical conditions for the development of the qualities of a competitive personality of a student of a technical university in the process of studying humanitarian disciplines (Doctoral dissertation, Om. State pedagogical university).

Saitbagina, L.A. (2015). The development of research activities of university students: the aspect of modeling. Bashkortostan Pedagogical Journal, 4, 103-107.

Tamarskaya, N. (2004). Competitiveness of the future teacher. Higher education in Russia, 3.

Zaitseva, O. Yu., Tyupenkova, G. Ye., Lysenko, N. V., Khamzina, L. N., \& Romanova, M. L. (2014). Modern models of a competitive personality. Scientific notes of the University. PF Lesgaft, 10 (116).

Received: 10 May 2021 | Accepted: 1 August 2021 | Published: 25 August 2021 